\title{
SOME ADAPTATIONS OF THE DESERT WOODLOUSE HEMILEPISTUS REAUMURI. (ISOPODA, ONISCOIDEA) TO DESERT ENVIRONMENT ${ }^{1}$
}

\author{
K. EDUARD LINSENMAIR
}

\section{Summary ${ }^{2}$}

The isopods discussed here live in steppes, semideserts and sporadically (Egypt, Algeria) real deserts of North Africa and Asia Minor. Occasionally too, they inhabit the marginal areas of salt lakes ('chott'). Measurements of population density demonstrate that they often belong to the most successful inhabitants of their biotopes.

Still unpublished experimental data show that $H$. reaumuri tolerates remarkably high temperatures and possesses comparatively effective protection against water loss through the cuticle. For example, one obtains transpiration rates of about 15 $\mu \mathrm{g} / \mathrm{cm}^{2} / \mathrm{h} / \mathrm{mm} \mathrm{Hg}$ from adult Hemilepistus kept at $30^{\circ} \mathrm{C}$ and $10 \%$ R.H., as compared with $110 \mu \mathrm{g}$ in Porcellio scaber (EDNEY, 1951). (Our own Measurements in freshly killed animals in which water discharge through the mouth was prevented (cf. LINDQUIST 1971, 1972), indicate only $90 \mu \mathrm{g}$.) The only known woodlouse showing comparably effective adaptations to xerie environment is Venezillo arizonicus (Armadillidae; WARBURG, 1965).

The physiological and morphological adaptations, however, are not a sufficient protection against the harsh climatic conditions.

The desert woodlice can survive the extreme heat of summer days only in the microclimate of the burrows which they dig themselves. Hemilepistus has not, specialized digging equipment; it is not able to excavate a new hole just any time necessity may demand. New burrows are dug only in early spring. The timely acquisition of a place in a burrow and its ensuing defense thus become central problems in the life of Hemilepistus.

The first $3-5 \mathrm{~cm}$ of a burrow is dug by a single woodlouse, with females digging more readily than males. Then it stops digging and guards its burrow continuously, defending it against every conspecific. Sooner or later the owner admits one single woodlouse of the opposite sex after a ritual which frequently lasts for hours.

The newly formed pair stays together normally until the death of one of the partners. There is a division of all labours between the two, including the uninterrupted guarding of the burrow entrance. In this connection it is surprising that, whichever of the pair happens to be the guard, rejects all strangers. The partner is recognized individually by chemical signals which are perceived by a chemotactic sense organ located on the tips of the second antennae.

Once a year (in North Africa in May) the female gives birth to 50-100 young. The young do not leave the burrow of their parents their first 10-20 days; there

1. Supported bei the Deutsche Forschungsgemeinschaft Li 150/6-150/9

2. I thank DR. R. LOFTUS for his valuable help with translating. 
they are fed by the parents. In leaving the burrow for the first time they avoid neighbouring burrows and direct contact with the young and the adults of other families. Adults admit only their own young to their burrow, other young are always driven away. The adults even try to catch and eat the young of their neighbours or feed them to their own offspring. Parents never attack their own young under normal conditions.

Parents recognize their young and the siblings one another by a family-specific chemical badge. Systematic cross tests showed the existence of at least hundreds, most probably thousands of family-badges.

These badges are very stable against environmental influences, as has been demonstrated by isolation experiments, by different feeding regimes, by keeping many families (148 resp. 100) for more than half a year under identical conditions in the laboratory etc. Thus the specificity of the badge is not the result of family differences in feeding, nor does it come from clinging odours picked up from the surroundings.

All findings concerning the family-badges indicate genetically determined secretions which are produced only by the young woodlice. The parents do not contribute by their own secretions to the family-badge. They are recognized by their young individually.

The parents learn the badge of their young soon after their birth. They also remain capable of learning to recognize an entirely different badge when forced, for example, to adopt a group of strange youngsters under experimental conditions.

The secretions of the young belonging to one family are not completely identical. Individual differences exist. The common family-badge is the product of mutual transfer and mixture of all individual secretions.

The behaviour of Hemilepistus fails to manifest any active exchange of secretions. The family-badges are transfered passively by direct body contact. Therefore, an exchange between members of different families can not be prevented if they are forced into contact: Mutual contact of two strangers lasting not more than 5 minutes is enough to make both unacceptable to their respective families for about 6 hours. Twenty minutes of enforced contact prolongues the period of unacceptability to 30 hours and more. When two family-badges are mixed, a completely new badge forms: When a mated pair is forced to adopt a group of young originating from two other families, they learn to recognize their foster young by their new mixed badge; siblings of the foster young which were kept separate and unmixed are always treated like complete strangers.

The chemical nature of the badges is being investigated intensively at the moment. From the results to date we conclude that the family-specific badges consist of relatively simple (i.e. not macromolecular), thermostable, strongly polar substances with a very low vapour pressure.

This system of family-specific badges enables a pair and their offspring to occupy a burrow to the exclusion of all conspecifics. The advantages are considerable: 1 . A burrow can offer protection only to a limited number of individuals. The family-badge assures the necessary limitation. 2. Food reserves in the vicinity of a burrow are often very meager and the radius of action of the woodlice hardly exceeds 5 meters. Thus the number of isopods the vicinity can support is also limited. 3. Most important, this system enables the parents to concentrate their broodcaring activities on their own young. When the young begin to seek nourish- 
ment for themselves they still remain dependent for weeks on the food gathered by their parents.

If woodlice are to prevent their neighbours' offspring from stealing their own offsprings' reserves, they must be able to distinguish strangers as such. The enormous variety of badges makes it almost impossible for two neighbouring families to have the same badge. The low vapour pressure and high stability of the badges against different influences from the environment guarantees entrance to the burrow to each member of the family even after prolongued excursions into strange surroundings and after ingestion of any nourishment, no matter how 'aromatic'. Two conditions, however, remain to be fulfilled: First, the woodlouse must be able to find its way home; it must possess effective orientation mechanisms; second, it must avoid close contact with strange young of another family. For contact would lead to a mutual exchange of badge substances. The result would be the masking of both family-badges and their replacement by a new one, a situation acceptable to neither family. This recognition system as developed by Hemilepistus can function only when the family units remain mutually exclusive. It cannot permit the integration even of individual strangers.

Along with its ability to dig, the desert woodlouse displays a social behaviour highly developed for invertebrates. This combination explains how a woodlouse which is physiologically not match for its environment can become one of the most successful inhabitants of a hot and dry biotope at the extreme end of the range. Details are published in LINSENMAIR, K.E. \& CH. LINSENMAIR, 1971, and LINSENMAIR, 1972 or will be published elsewhere.

\section{REFERENCES}

EDNEY, E.B. (1951): The evaporation of water from woodlice and the millipede Glomeris. J. Exp. Biol. 28: 91-115.

LINDQUIST, O.V. (1971): Evaporation in terrestrial isopods is determined by oral and anal discharge. Experientia $27: 1496-1498$.

- (1972): Components of water loss in terrestrial isopods. Pbysiol. Zool. 45: 316-324.

LINSENMAIR, K.E. \& LINSENMAIR, CH. (1971): Paarbildung und Paarzusammenhalt bei der monogamen Wüstenassel Hemilepistus reaumuri (Crustacea, Isopoda, Oniscoidea).

Z. Tierpsychol. 29: 134-155.

LINSENMAIR, K.E. (1972): Die Bedeutung familienspezifischer ,Abzeichen“ für den Familienzusammenhalt bei der sozialen Wüstenassel Hemilepistus reaumuri AUDOUIN u. SAVIGNY (Crustacea, Isopoda, Oniscoidea) Z. Tierpsycbol. 31: 131-162.

WARBURG, M.R. (1965): Water relations and internal body temperature of isopods from mesic and xeric habitats. Pbysiol. Zool. 38: 99-109.

Anschrift des Verfassers:

Prof. Dr. K. EDUARD LINSENMAIR, Fachbereich Biologie der Universität D - 84 Regensburg, Universitätsstraße 31 . 